\title{
Construction of an Infectious CDNA Clone of a Swine Genotype 3 HEV Strain Isolated in Shanghai, China
}

\author{
Fusheng $\mathrm{Si}^{\mathrm{a}}$ Biao Shi ${ }^{\mathrm{a}} \mathrm{Xi} \mathrm{Wang}^{\mathrm{a}}$ Yumin Zhu ${ }^{\mathrm{a}}$ Xia Liu ${ }^{\mathrm{b}}$ Qian Yang ${ }^{\mathrm{c}}$ Zhen $\mathrm{Li}^{\mathrm{a}}$ \\ ${ }^{a}$ Institute of Animal Science and Veterinary Medicine and Shanghai Key Laboratory of Agricultural Genetics and \\ Breeding, Shanghai Academy of Agricultural Sciences (SAAS), Shanghai, ${ }^{b}$ Department of Immunology, School of \\ Medical Science and Laboratory Medicine, Key Discipline of Clinical Medical Science of Jiangsu Province, Jiangsu \\ University, Zhenjiang, and ${ }^{\mathrm{C} C o l l e g e ~ o f ~ V e t e r i n a r y ~ M e d i c i n e, ~ N a n j i n g ~ A g r i c u l t u r a l ~ U n i v e r s i t y, ~ N a n j i n g, ~ P R ~ C h i n a ~}$
}

\section{Key Words}

Genotype 3 HEV · Infectious cDNA clone · Animal model ·

Sprague-Dawley rats

\begin{abstract}
Objectives: Infectious cDNA clones are important tools for studying molecular mechanisms in RNA viruses. The aim of this study was to construct an infectious cDNA clone for SAAS-JDY5, which is a genotype $3 \mathrm{HEV}$ strain of swine origin. Methods: Construction employed overlapping PCR and restriction analysis to ligate nine cDNA fragments into a fulllength cDNA clone containing 14 mutations compared to the consensus HEV genome sequence. Megaprimer PCR-directed mutagenesis restored nine non-silent mutations back to the consensus sequence while the other five silent mutations were maintained as genetic markers. Results: HEV proteins were identified by an immunofluorescence assay in Huh7 cells infected with capped RNA transcripts of the fulllength cDNA clone, while HEV viremia, fecal HEV RNA and seroconversion were recorded in inoculated Sprague-Dawley rats. Conclusions: Our data confirmed the successful construction of an infectious CDNA clone of swine HEV strain pGEM4Z-SAAS-JDY5, and support the use of rats as an HEV infectious model.

(c) 2014 S. Karger AG, Basel
\end{abstract}

\section{KARGER}

(c) 2014 S. Karger AG, Basel

0300-5526/14/0572-0074\$39.50/0

E-Mail karger@karger.com

www.karger.com/int

\section{Introduction}

Hepatitis E is an important public health concern in many developing countries [1]. The disease is believed to be transmitted by the fecal-oral route, and is caused by hepatitis $\mathrm{E}$ virus (HEV), a non-enveloped virus with a genome of single-stranded, positive-sense RNA [2-5]. Hepatitis $\mathrm{E}$ is characterized by jaundice, fever, nausea and vomiting, is usually self-limiting, and only rarely progresses to fulminant hepatitis [6]. The overall mortality rate is usually less than $1 \%$, but may be as high as $28 \%$ in infected pregnant women, particularly during the third trimester of pregnancy, with significant risks to the fetus [7-9].

The HEV genome is approximately $7.2 \mathrm{~kb}$ in length and consists of a short $5^{\prime}$ non-coding region (NCR), three partially overlapping open reading frames (ORFs 1,2 and 3) [10-12], and a short $3^{\prime}$ NCR terminated by a poly A tail [13-15]. ORF1 encodes non-structural proteins involved in viral replication, ORF 2 an immunogenic structural protein $[13,16-18]$ and ORF3 a small cytoskeleton-associated phosphoprotein $[11,19,20]$. Although only one serotype is recognized [21], the HEV genome displays extensive genetic diversity [10] and, based on full-length genomic sequences and phylogenetic analyses, HEV strains have been classified into at least four mammalian genotypes (designated 1-4) and one

Dr. Zhen Li

Institute of Animal Science and Veterinary Medicine and Shanghai Key Laboratory of Agricultural Genetics and Breeding, Shanghai Academy of Agricultural Sciences (SAAS) Shanghai 201106 (PR China)

E-Mail zhenli60@163.com 
avian HEV [10, 22]. Genotype 1 has been reported in China and several other Asia and African countries, while genotype 2 has so far been confined mainly to Mexico. Epidemics of genotype 3 have been reported in many regions including North America, Europe and some Asian countries [23-28], and of genotype 4 in several Asian countries. Recently, several other novel hepeviruses have been isolated from HEV infections of rabbits [29], rats [30-34], bats [35] and cut-throat trout [36]. Among the four mammalian genotypes, genotypes 1 and 2 have so far been restricted to humans and associated with large waterborne epidemics [37], while accumulating evidence indicates that genotypes 3 and 4 are common in both humans and animals, and are responsible for sporadic cases of hepatitis E [30, 38, 39].

In 2007, swine genotype $3 \mathrm{HEV}$ was reported in Shanghai [25], and a strain designated SAAS-JDY5 was isolated later for full-length genome sequence analysis [40]. More recently, a human genotype $3 \mathrm{HEV}$ infection was reported in Jiangsu Province adjoining the municipality of Shanghai [41] and, since this genotype is evidently an emerging infectious disease agent in China for both animals and humans, there is a clear need for more research on the mechanisms of cross-species transmission and the evolution of genotype $3 \mathrm{HEV}$ in the region. Reverse genetics represents a powerful tool for such studies, with the development of an infectious cDNA clone of HEV the first step in the process. Non-human primates and swine have generally been employed as infection models in HEV research although, for both ease of handling and economic reasons, smaller animal models are preferred. Antibodies to HEV, and even viral RNA, have been detected in wild rats in the USA, Japan, Nepal, and China [42-45], and the possibility of this rodent serving as an animal model was given further credence by a recent report describing experimental infections of Sprague-Dawley (SD) rats with swine HEV [46].

In this study, a cDNA clone of pGEM4z-SAAS-JDY5 has been successfully constructed using a combination of overlapping PCR and restriction analysis, and the infectious capacity of the clone was demonstrated initially using Huh7 cells. SD rats were inoculated with transcripts of the clone to verify its infectious ability in vivo and to confirm the validity of the animal model.

\section{Materials and Methods}

Plasmid and Tissue Cell Line

RACE was used to amplify the $5^{\prime}$ and $3^{\prime}$ UTR ends, and the remaining seven fragments were acquired by overlapping PCR as described previously [40]. A subclone of the human hepatoma cell line Huh7 was grown as a monolayer in Dulbecco's modified Eagle's medium (DMEM) supplemented with $2 \mathrm{mM} \mathrm{L}$-glutamine and $8 \%$ fetal bovine serum in a $5 \% \mathrm{CO}_{2}$ incubator at $37^{\circ}$. Transfected and infected cells were maintained in a $5 \% \mathrm{CO}_{2}$ incubator at $34.5^{\circ}$.

Construction of a Full-Length Infectious cDNA Clone of Genotype 3 HEV and Megaprimer PCR-Directed Mutagenesis

Nine previously amplified fragments [40] encompassing the entire SAAS-JDY5 genome were used as the template for the construction of a full-length cDNA clone of HEV adopting the strategy outlined in figure 1 . Firstly, fragment $5^{\prime}-2\left(\mathrm{~F} 5^{\prime}-2\right)$ was obtained by overlapping PCR using primers $5^{\prime}-\mathrm{S}$ and I2-A (table 1 ) and three overlapping fragments $\left(5^{\prime}, 1,2\right)$ as template. Fragments 3-4, 5-6 and 6-3' were similarly obtained using primer pairs I3-S/I4-A, I5-S/I6-A and I6-S/3'-A, respectively. The original nine overlapping fragments were thereby reduced to four (fig. 1). Next, F3-4 and F5-6 were ligated into F3-6 using the $k p n$ I restriction site located in the overlapping region of F4 and F5, before fusing together F5'-2 and F3-6 into fragment F5' -6 by overlapping PCR using primers $5^{\prime}-\mathrm{S}$ and I6-A. The full-length $\mathrm{CDNA}$ was obtained using the FseI restriction site located in the overlapping region of $\mathrm{F} 5$ and F6 as follows: F6- $3^{\prime}$ was amplified with primer pairs 15bp + P6S and 15bp + NUP-A (table 1), and the amplified product was then ligated to FseI-digested F5'-6 by the In-fusion Reaction using EZfusion PCR Cloning Kit (Generay, Shanghai, China). This fulllength cDNA fragment was again amplified with PrimeSTAR ${ }^{\mathrm{TM}}$ HS DNA Polymerase (TaKaRa, Japan) using the primer pairs $\mathrm{XbaI} / \mathrm{CS}$ and HindIII/CA in order to introduce the XbaI restriction site and T7 RNA polymerase core promoter to the extreme $5^{\prime}$ terminus, and a short stretch of 15 adenosine residues (A) and the HindIII site to the $3^{\prime}$ end (fig. 1). The amplified product was digested with $\mathrm{XbaI}$ and HindIII, ligated into the pGEM- $4 \mathrm{z}$ vector (Promega), and the recombinant plasmid containing the fulllength cDNA of SAAS-JDY5 was designated pGEM4z-SAASJDY5.

pGEM4z-SAAS-JDY5 was then subjected to complete sequencing and, after comparison with the parental genotype 3 SAAS-JDY5 sequence, non-silent mutations were subsequently corrected by megaprimer PCR mutagenesis using the primers listed in table 2. After mutagenesis, the entire cDNA sequence was checked to verify that no unwanted mutations had been introduced.

\section{Animals and Antibodies}

Sixteen 3-week-old, 50-80 g specific-pathogen-free (SPF) female SD rats were provided by the National Rodent Laboratory Animal Resources, Shanghai Branch (China) and maintained in a pathogen-free animal facility (Certificate No. 2007000512630). The experimental protocol was approved by the Animal Care and Use Committee (ACUC) of the Shanghai Research Center for Biomodel Organisms. Polyclonal anti-ORF2 (PCorf2) antibodies were raised in a rabbit inoculated with purified ORF2 protein of genotype $3 \mathrm{HEV}$ [unpubl. data].

Transcription in vitro and Transfection of Cultured Cells

Plasmids were linearized at the HindIII site for RNA transcription. Capped transcripts were synthesized with the T7 Riboprobe in vitro transcription system (Promega) in $50-\mu \mathrm{l}$ reaction mixtures 
Table 1. Oligonucleotide primers used for the construction and characterization of the HEV infectious cDNA clone

\begin{tabular}{ll}
\hline Primer ID & Sequence $\left(5^{\prime}-3^{\prime}\right)$ \\
\hline $5^{\prime}-\mathrm{S}$ & GGCAGACCACGTATGTGGTCG \\
I2-A & ACCAGCCAGTCGCAATCT \\
I3-S & TTGGGAGTCTGCTAACCCTT \\
I4-A & GCTATGATTGCCATGTTCC \\
I5-S & CCCTGCTCCCGCCTAATA \\
I6-A & TTGGTGGAGGTCCCATAC \\
I6-S & AGGGCTGTTCTGTTGCTG \\
$3^{\prime}-A$ & GTCCGGGGAGCGCGGAAAGC \\
$15 b p+$ P6S & TTTTGCCTATGCTGCCCGCGCCACCGGCCGGCCA \\
15bp + NUP-A & CAGACGGCTGGCCGGTCTAGAAGCAGTGGTATCAACGCAG \\
XbaI-CS & TGCtctagaTAATACGACTCACTATAGGGGCAGACCACGTATGTGGT \\
HindIII-CA & CGCagacttTTTTTTTTTTTTTTCGGGGAGCGCGGAAAGCAGA \\
E1S & CTTGGCGAATGCTGTGGT \\
E1A & GCTGTAGAGCCTTGTAATGAAC \\
E7S & CGCAGCAGGACAAGGGTA \\
E7A & GGCGGGGTAATCAACAGT \\
I7S & TGACAACCAGCACGAACA \\
I7A & GTCCTCAAGAACAGCAAGC \\
\hline
\end{tabular}

Fig. 1. The strategy for assembly of the fulllength HEV cDNA clone pGEM4z-SAASJDY5. a The numbers on the scale bar indicate distances in kilobases from the $5^{\prime}$ end. b Nine cDNA fragments synthesized by RT-nPCR distributed according to the genomic organization of HEV. Steps 1-5 describe the stages in the construction of the full-length cDNA clone, pGEM4zSAAS-JDY5, using overlapping PCR, enzyme ligation and in-fusion reactions. A unique XbaI site and a T7 RNA polymerase core promoter were engineered at the $5^{\prime}$ end, and a 15-nt short poly (a) tail and a unique HindIII site were introduced at the $3^{\prime}$ end of the genome. Finally, the constructed plasmid was double-digested at the $\mathrm{XbaI} / \mathrm{Hind}$ III restriction sites and inserted into the $\mathrm{pGEM}-4 \mathrm{z}$ vector (Promega) to produce the full-length cDNA clone, pGEM4z-SAAS-JDY5.

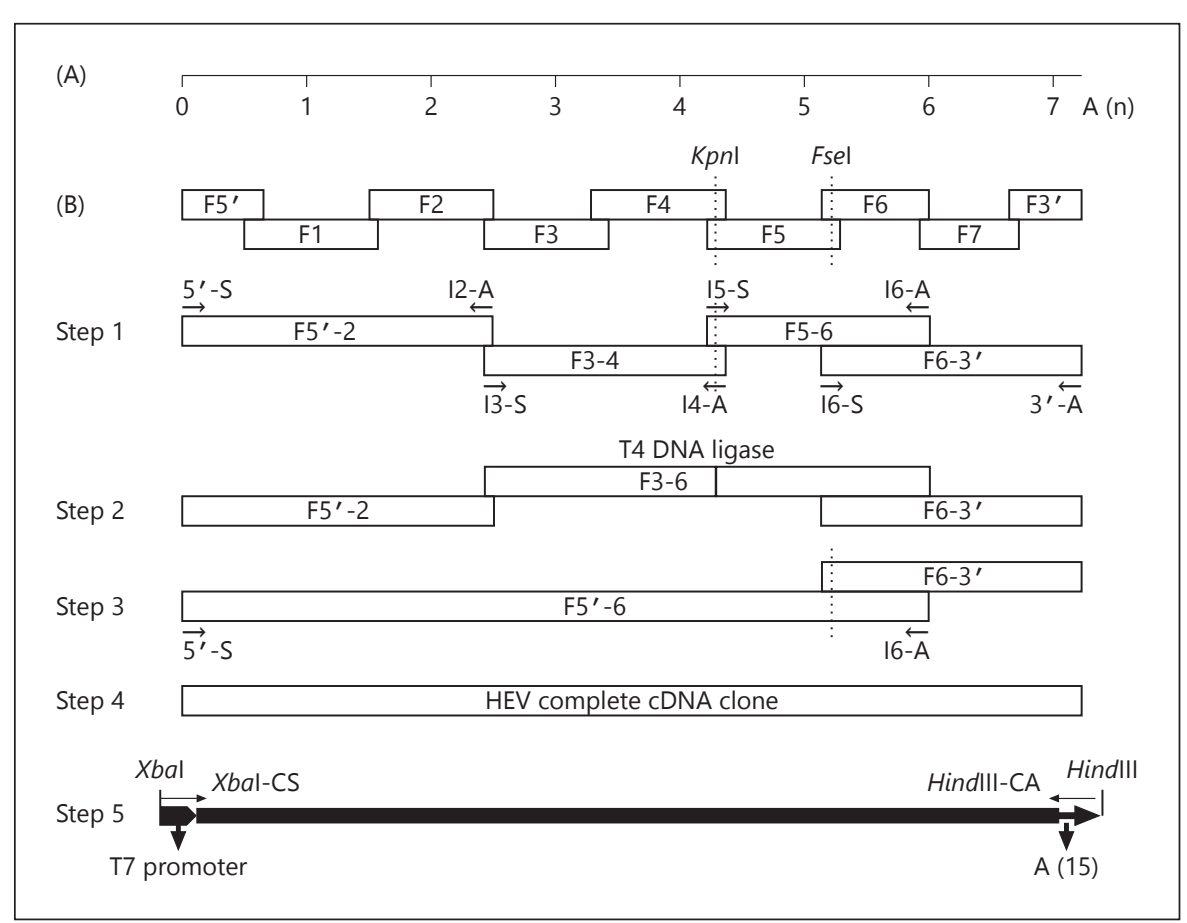

containing $5 \mu \mathrm{g}$ linearized cDNA template, $10 \mu \mathrm{l}$ Transcription Optimized $5 \times$ buffer, $5 \mu \mathrm{l} 100 \mathrm{mM}$ DTT, $2 \mu \mathrm{l} 40 \mathrm{U} / \mathrm{ml}$ Recombinant Rnasin ${ }^{\circledR}$ Ribonuclease Inhibitor, $10 \mu$ nucleotides $(2.5 \mu$ l each of $10 \mathrm{mM}$ rATP, rCTP, rUTP plus $2.5 \mu \mathrm{l} 1 \mathrm{mM}$ rGTP), $5 \mu \mathrm{l} 5 \mathrm{~mm}$ Ribo $\mathrm{m}^{7} \mathrm{G}$ Cap Analog, $2 \mu \mathrm{l} 20 \mathrm{U} / \mathrm{ml}$ T7 polymerase and $11 \mu \mathrm{l}$ of nuclease-free water. A negative control sample was identical to the reac- tion mixture described above except that T7 polymerase was omitted and replaced with water. Mixtures were incubated at $37^{\circ}$ for $1.5 \mathrm{~h}$, followed by treatment with RQ DNase I for $30 \mathrm{~min}$ at $37^{\circ}$. For intrahepatic inoculation into SD rats, the RNA transcripts were diluted 1:2 with cold RNase-, DNase- and proteinase-free PBS, frozen at $-70^{\circ}$ and used within 2 days. 
Table 2. Oligonucleotide primers used for the megaprimer PCR mutagenesis of the HEV infectious cDNA clone

\begin{tabular}{ll}
\hline Primer ID & Sequence $\left(5^{\prime}-3^{\prime}\right)$ \\
\hline C2220T-f & TGCCCCAGGGTTGCCCTGTCCTACTCCA \\
G2311A-r & CAGCAGGCTC AGGGGCAGGT GGGACAGA \\
C3075T-f & GTAATAACTGGCGCCGCTGGGGCTTTGC \\
G3688A-r & TATCACAGAG GGGCGGTGATGACCCACCTC \\
A4699G-f & GGGTTGCTGCCTTTAGGGGTGATGATTC \\
C4861T/G4888A-f & CTGATGTAGTGCGTTTTGCTGGTCGGTTATCTGAAAAGGATTGG \\
T5104C/T5112C-r & GATGTAT GATTGGGTTT GTAGGATCAA GCACAG \\
\hline
\end{tabular}

For transfection, Huh7 cells in 6-well plates were incubated with $900 \mu \mathrm{l} /$ well transfection solution for $6 \mathrm{~h}$ at $34.5^{\circ}$. The transfection solution consisted of $878 \mu$ l Opti-MEM (Invitrogen), $2 \mu \mathrm{l}$ DMRIE-C (Invitrogen) and transcription mixture $(20 \mu$ l containing $50 \mu \mathrm{g}$ RNA). The transfection solution was then replaced with $1.5 \mathrm{ml}$ DMEM supplemented with $2 \mathrm{mM}$ L-glutamine and $8 \% \mathrm{fe}$ tal bovine serum, and incubated under the same conditions for 7-8 days.

\section{Immunofluorescence Microscopy}

Seven or 8 days post-transfection, an immunofluorescence assay (IFA) was used to detect viral protein synthesis in Huh7 cells transfected with the full-length RNA transcripts. Huh7 cells were grown in 6-well plates for transfection as described above. On day 5 of transfection, cells were trypsinized and half the total was discarded. Fresh medium was added to the remainder, which were then transferred to 24-well plates containing glass slides for the cells to grow on, cultured for a further 2 days before fixing and staining. Briefly, the cells were washed with PBS, fixed with fixing solution ( $80 \%$ acetone and $20 \%$ methanol) and air dried before incubation for $40 \mathrm{~min}$ at room temperature with a 1:1 mixture of $10 \%$ bovine serum albumin and PBS containing PCorf2. The cells were then washed 3 times with PBS and counterstained for 35 min with PBS containing Alexa Fluor 488-conjugated goat anti-rabbit IgG (Invitrogen). The slides were washed 3 times with PBS, covered with Vectashield mounting solution, and dried in the dark prior to examination using a fluorescence microscope.

\section{Detection of HEV Negative-Strand RNA}

Cells were harvested and lysed in TRIzol reagent (Invitrogen Life Technologies) at various time points post-transfection. Total RNA from the cells was isolated and resuspended in diethyl pyrocarbonate-treated water. For strand-specific RT-PCR, complementary DNA of the negative strand was synthesized using a strand-specific primer: S1 (forward, $5^{\prime}$-CTGTTTAAYCTTGCT GACAC- $3^{\prime}$ ). Reverse transcription was performed at $42^{\circ}$ for $60 \mathrm{~min}$ in $25-\mu \mathrm{l}$ reaction mixtures containing $9 \mu$ total RNA (template), $1 \mu \mathrm{l}$ S1 primer $(10 \mu \mathrm{M}), 40 \mathrm{U}$ M-MLV Reverse Transcriptase (Promega) in $5 \mu \mathrm{l}$ M-MLV $5 \times$ Reaction Buffer, $5 \mu \mathrm{l}$ dNTP Mix (10 $\mu \mathrm{M}$ each) and $25 \mathrm{U}$ Ribonuclease Inhibitor (Promega). Reverse transcriptase activity was then heat-inactivated at $72^{\circ}$ for 10 min before amplification of the region within the ORF2 gene from nt 6321-6509 using nested PCR. First-round PCR was performed with a set of degenerate HEV primers: $S 1$ (forward, $5^{\prime}$-CT
GTTTAAYCTTGCTGACAC- $3^{\prime}$ ) and A1 (reverse, 5'-WGA RAGCCAAAGCACATC- $3^{\prime}$ ) in $25-\mu$ reaction mixtures containing $0.5 \mu \mathrm{l}$ cDNA (template), $5 \mathrm{U}$ PrimeSTAR ${ }^{\mathrm{TM}} \mathrm{HS}$ DNA Polymerase in $2.5 \mu \mathrm{l}$ of $5 \times$ PrimeSTAR Buffer (Takara, Japan), $4 \mu \mathrm{dNTPs}(2.5 \mu \mathrm{M}$ each $)$ and $10 \mathrm{mM}$ of each primer. Amplification conditions were: 5 min at $94^{\circ}, 30$ cycles of $94^{\circ}$ for $30 \mathrm{~s}, 53^{\circ}$ for $30 \mathrm{~s}$, and $72^{\circ}$ for $40 \mathrm{~s}$, followed by a final extension of $10 \mathrm{~min}$ at $72^{\circ}$. Second-round PCR was performed with HEV GST primers: S2 (forward, 5'-GACAGAATTGATTTCGTCG-3') and A2 (reverse, $5^{\prime}$-TGTTGGTTRTCATAATCCTG- $3^{\prime}$ ) in $50-\mu l$ reaction mixtures containing $5 \mu \mathrm{l}$ of the first-round PCR product (template) under the same conditions as above. The expected final product of the nested RT-PCR was $150 \mathrm{bp}$. Amplified products were separated by electrophoresis on $1 \%$ agarose gels and photographed with a UVP gel-documentation system. Negative controls for RT, first-round PCR and nested PCR consisting of nontransfected cells were included in each run.

\section{Intrahepatic Inoculation of SPF SD Rats with Capped RNA}

Transcripts of the Genotype 3 HEV cDNA Clone

Sixteen SPF SD rats, negative for fecal HEV and serum antibodies, were randomly divided into four equal groups (A-D), and each group was housed separately in a biosafety level 2 facility and maintained under conditions that met all the requirements of the Institutional Committee on Animal Care and Use.

Rats in group A (Nos. 1-4) and group B (Nos. 5-8) were inoculated at multiple sites in the liver with 50 - and $500-\mu \mathrm{g}$ transcripts, respectively after performance of a minilaparotomy. Rats in group D (Nos. 13-16) (negative controls) were injected with PBS and kept under the same conditions. Rats in group C (Nos. 9-12) (positive controls) were each injected both intrahepatically and intravenously with $200 \mu \mathrm{l}$ of a fecal sample that had been filtered through a $0.22-\mu \mathrm{m}$ microfilter (Millex-GV; Millipore Corp., Bedford, Mass., USA) and was positive for the prototype strain, SAAS-JDY5. Serum and fecal samples were collected at 0 , $3,7,14,21,28,35,45,50$ and 55 days post-inoculation (dpi) and stored at $-70^{\circ}$ for further study.

\section{RT-nPCR and ELISA}

Fecal and sera samples were tested for genotype 3 HEV RNA and HEV antibodies using RT-nPCR and ELISA (Wantai Biopharmaceutical, Inc., Beijing, China), respectively [47]. All assay procedures were carried out according to the manufacturer's instructions. Cut-off values for the HEV antibody assay were determined based on 0.12 (standard deviation) plus the mean OD 450/630 val- 
Fig. 2. Immunofluorescent staining of Huh7 cells transfected with RNA transcripts from the HEV cDNA clone of pGEM4z-SAAS-JDY5 (a), and mocktransfected cells (negative control) (b).
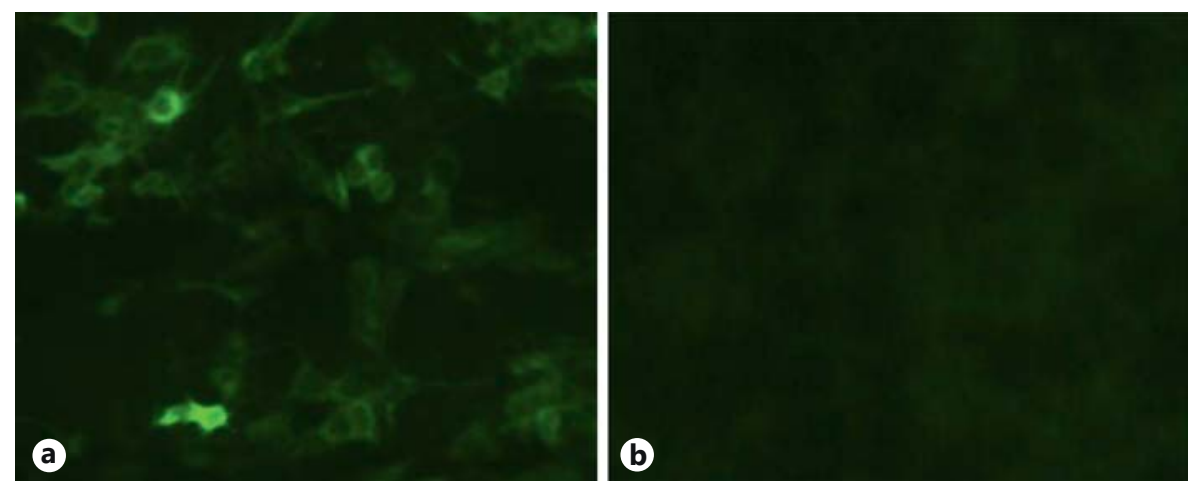

Table 3. Mutations in the cDNA clone compared with the consensus sequence of genotype 3 swine HEV genome

\begin{tabular}{rlll}
\hline Position & Genome region & Consensus & Mutation \\
\hline 455 & Methyl domain & $\mathrm{C}$ & $\mathrm{T}^{\mathrm{c}}$ \\
1667 & PCP & $\mathrm{G}$ & $\mathrm{A}^{\mathrm{c}}$ \\
2220 & ORF1 & $\mathrm{T}$ & $\mathrm{C}^{\mathrm{d}}$ \\
2311 & ORF1 & $\mathrm{A}$ & $\mathrm{G}^{\mathrm{d}}$ \\
3075 & ORF1 & $\mathrm{T}$ & $\mathrm{C}^{\mathrm{d}}$ \\
3688 & ORF1 & $\mathrm{A}$ & $\mathrm{G}^{\mathrm{d}}$ \\
4699 & ORF1 & $\mathrm{G}$ & $\mathrm{A}^{\mathrm{d}}$ \\
4861 & ORF1 & $\mathrm{T}$ & $\mathrm{C}^{\mathrm{d}}$ \\
4888 & ORF1 & $\mathrm{A}$ & $\mathrm{G}^{\mathrm{d}}$ \\
5104 & ORF1 & $\mathrm{C}$ & $\mathrm{T}^{\mathrm{d}}$ \\
5112 & ORF1 & $\mathrm{C}$ & $\mathrm{T}^{\mathrm{d}}$ \\
6024 & ORF2 & $\mathrm{T}$ & $\mathrm{C}^{\mathrm{c}}$ \\
6510 & ORF2 & $\mathrm{T}$ & $\mathrm{C}^{\mathrm{c}}$ \\
6513 & ORF2 & $\mathrm{G}$ & $\mathrm{A}^{\mathrm{c}}$ \\
\hline
\end{tabular}

${ }^{a}$ Methyltransferase domain. ${ }^{b}$ Papain-like cysteine protease. ${ }^{\mathrm{c}}$ Silent mutation. ${ }^{\mathrm{d}}$ Non-silent mutation.

ues of sera from three negative controls. Samples with OD values less than the cut-off value were considered negative, whereas samples with OD values greater than or equal to the cut-off value were tentatively considered reactive.

Detection of Genetic Markers in Viruses Recovered from

Experimentally Infected Rats

RT-nPCR was used to detect the presence of genetic markers in rescued viruses from fecal samples taken from rats in groups $\mathrm{A}$ and B. The primer pair E1S/E1A was employed to amplify the genetic marker at nt 455 of the ORF1 region, and external primers E7S/E7A and internal primers I7S/I7A (table 1) in our previous study [40] was used to amplify the genetic markers at nt 6510 and 6513 of the ORF2 region. PCR products were excised from 1.5\% agarose gels and purified using the Axyprep DNA Gel Extraction Kit (Axygen, Union City, Calif., USA) for sequencing.

\section{Results}

Construction of a Full-Length Infectious cDNA Clone of SAAS-JDY5

Sequencing of the assembled full-length cDNA clone and comparison with the consensus sequence confirmed the presence of five silent mutations and nine non-silent mutations (table 3 ). The latter were corrected to the consensus sequence of SAAS-JDY5, and the silent mutations at nt 455, 6510 and 6513 in the clone were retained for genetic identification.

\section{Replication of the Full-Length cDNA Clone in \\ Transfected Huh7 Cells}

An IFA using PCorf2 revealed the presence of viral antigens in Huh7 cells following transfection with capped RNA transcripts from the HindIII-linearized pGEM4zSAAS-JDY 5 cDNA clone (fig. 2). Further proof of HEV genome replication was provided by the detection of negative-sense HEV RNA in infected Huh7 cells 7 days posttransfection (dpt) (fig. 3). No negative-strand amplification was evident in mock-infected cells.

\section{Infectivity of Capped RNA Transcripts of pGEM4Z-SAAS-JDY5 for SD Rats}

Most rats in groups A and B underwent seroconversion to anti-HEV between 14 and 55 days following intrahepatic injection with capped RNA transcripts of pGEM4z-SAAS-JDY5 (table 4), indicating that active HEV infection had occurred. Rats in groups $\mathrm{B}$ and $\mathrm{C}$ began to undergo seroconversion $14 \mathrm{dpi}$, and animals in group $\mathrm{A}$ at $21 \mathrm{dpi}$. Variable fecal virus shedding was detected in all inoculated animals in groups $\mathrm{A}, \mathrm{B}$ and $\mathrm{C}$. HEV RNA was first detected 14 dpi in group A and 7 dpi in group B, and lasted until 55 dpi. Similar detection patterns were recorded for serum viral RNA. None of the rats 
Fig. 3. Intracellular replication of $\mathrm{HEV}$ in Huh7 infected cells. Detection of $\mathrm{HEV}$ RNA in Huh7 cells at 0,7 and 14 days posttransfection. Negative-strand HEV RNA in Huh7 cells was detected by amplification of a 150-bp ORF1 partial sequence after synthesis of negative strand cDNA.

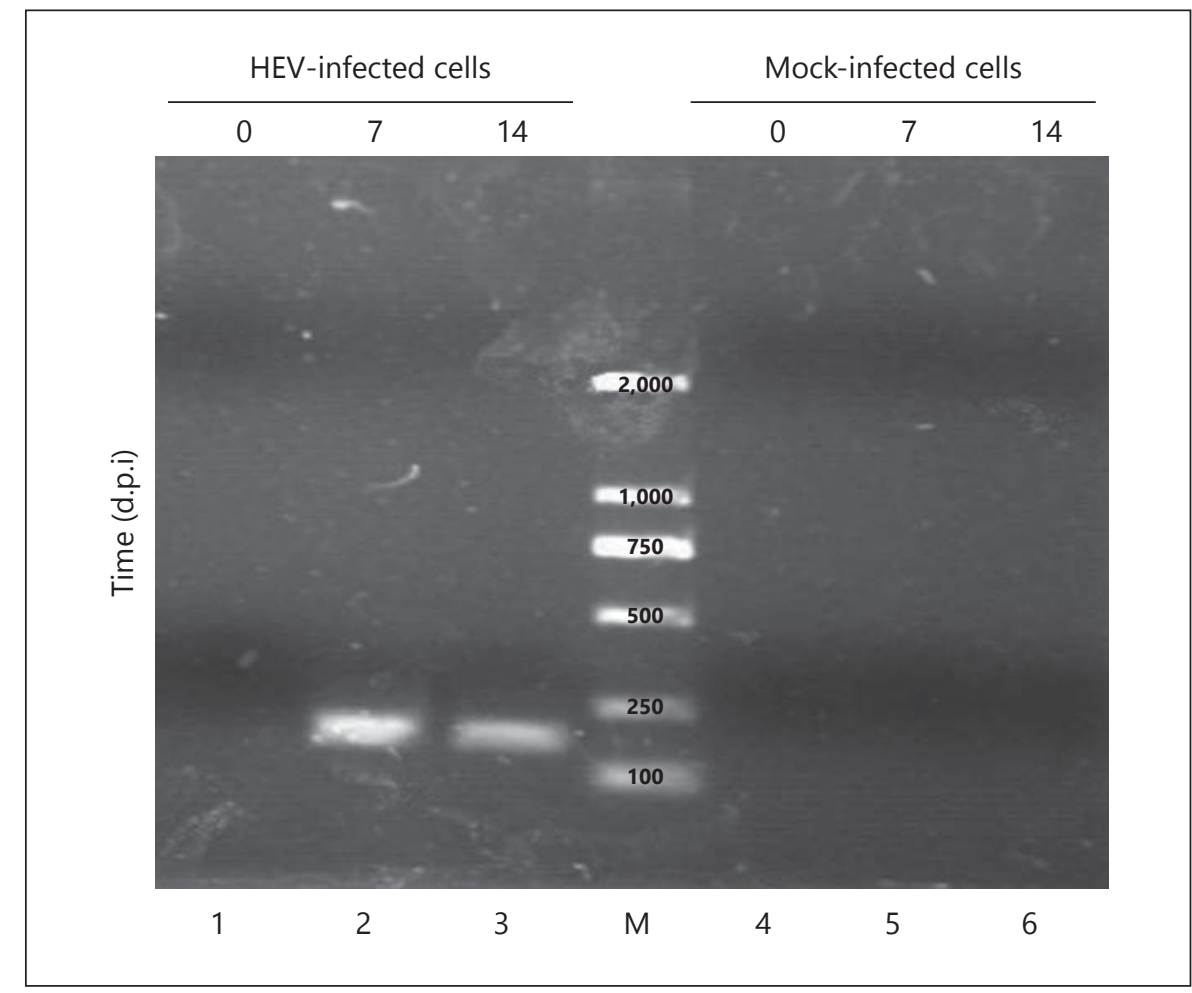

Table 4. Appearance of fecal HEV RNA, viremia and HEV antibodies in different rat samples

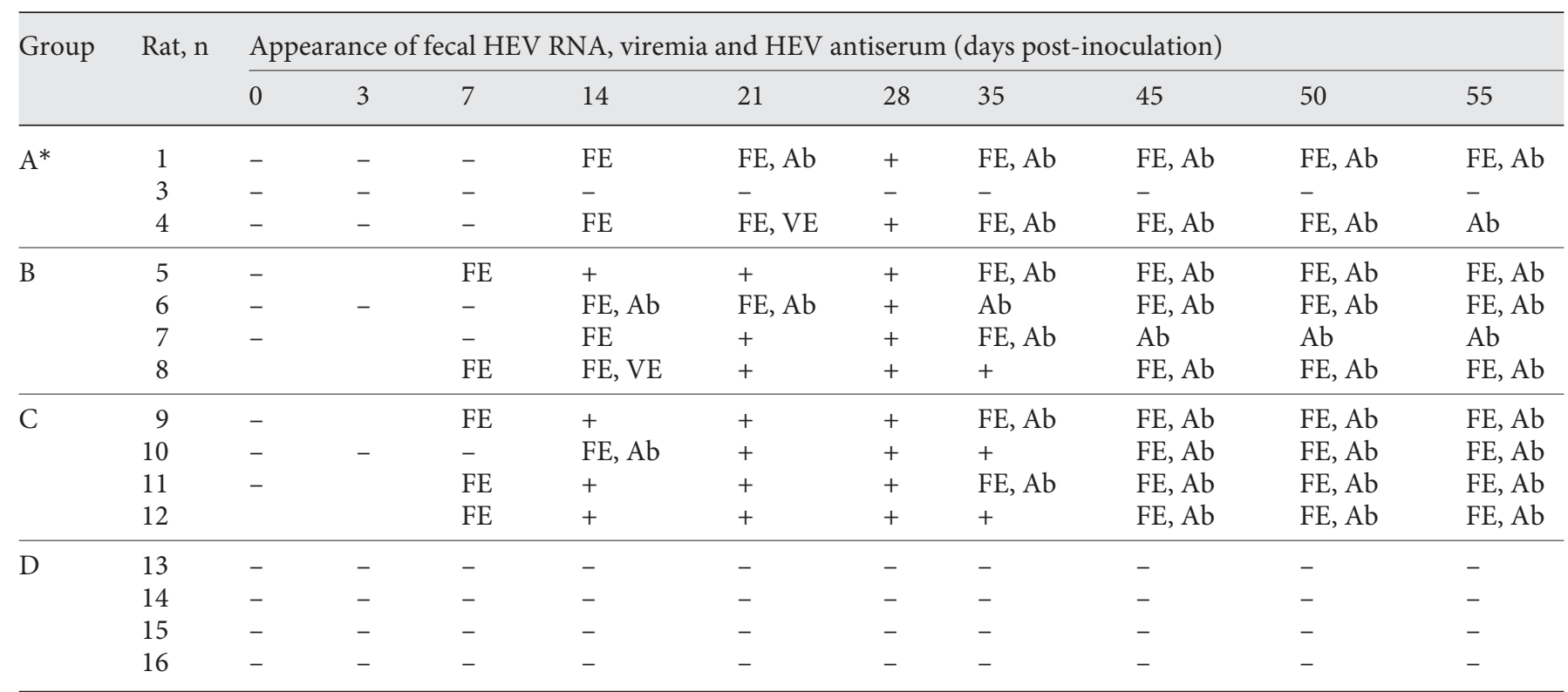

FE, VE and Ab indicate fecal HEV excretion, viremia and serum HEV antibodies, respectively; + and - indicate complete positivity and negativity for all three parameters.

* One rat died 2 days post-inoculation. 
in the negative control group tested HEV RNA-positive or exhibited fecal virus shedding throughout the experimental period.

\section{Detection of Genetic Markers in Viruses Recovered from Infected Rats}

Sequence analysis revealed the presence of the genetic markers at nt 455, 6510 and 6513 of the genome of viruses recovered from the feces of rats in groups A and B, confirming that the infecting virus originated from the full-length cDNA clone, pGEM4z-SAAS-JDY5.

\section{Discussion}

Reverse genetic systems are highly useful tools for studying RNA virus replication, pathogenesis and in vivo functionality of individual viral proteins. As an initial step in their application to HEV research, we have constructed a full-length HEV genomic cDNA clone adopting a similar strategy used to prepare several infectious cDNA clones $[20,48-50]$ involving the ligating together of amplified fragments via appropriate restriction sites. In this study, we successfully fused nine DNA fragments into four larger ones, and then ligated the latter into the fulllength cDNA using additional rounds of overlapping PCR and restriction ligation.

Extensive usage of PCR introduces unexpected mutations into the amplified cDNA sequences, 14 of which were generated during the construction of the infectious cDNA clone. Nine non-silent mutations were corrected by megaprimer PCR mutagenesis and, since we know of no reports of silent mutations interfering with genomic or sub-genomic replication in these systems, the remaining five silent mutations were left unchanged as genetic markers of the cDNA clone. Recovery following animal inoculation of transcripts of the cDNA clone supported our conclusion that these silent mutations did not affect the rescue of the recombinant virus.

Our IFA demonstrated only that translation of HEV proteins had occurred in transfected Huh7 cells, whereas the inoculation tests on SD rats provided strong evidence of the infectious ability of the capped RNA transcripts of the cDNA construct. However, 1 rat in group A (50 $\mu \mathrm{g}$ dosage) remained negative of all test parameters throughout the experimental period. Two others in the group exhibited delayed seroconversion, fecal virus shedding and viremia compared with groups B (500 $\mu \mathrm{g}$ dosage) and group $\mathrm{C}$ (wild-type virus), suggesting that a high threshold level of RNA transcripts was required to guarantee a successful infection. A need for higher dose rates was also indicated by the recent report of low susceptibility among SD rats infected with swine HEV [46].

The occurrence of fecal HEV RNA, HEV viremia and HEV antibodies in the inoculated SD rats supported earlier suggestions that experimental rats might serve as alternatives to swine and non-human primates for $\mathrm{HEV}$ testing $[42,51,52]$. These different animal models exhibit similar infection dynamics. For example, we first detected HEV RNA in rat feces $7 \mathrm{dpi}$, similar to results obtained with pigs [53], laboratory rats [52] and cynomolgus macaques [54]. Furthermore, the onset (14 dpi) of anti-HEV seroconversion that occurred in this study was similar to that previously reported for pigs [55]. Moreover, the time of onset and duration of viremia in rats and pigs, approximately $14 \mathrm{dpi}$ and 3 weeks respectively, were also comparable [56].

In conclusion, we have successfully used a more flexible strategy to construct an infectious cDNA clone of pGEM4z-SAAS-JDY5, which contained five genetic markers on the coding genes of ORF1 and ORF2. Our research strongly indicates that $\mathrm{SD}$ rats can serve as an animal model for HEV research.

\section{Acknowledgments}

We thank Dr. John Buswell, Institute of Edible Fungi, SAAS, for linguistic revision of the manuscript. This research was supported by grants from the Shanghai Municipal Natural Science Foundation (No. 09ZR1428100), the Shanghai Academy of Agricultural Sciences (SAAS) Fund for Youth Scientists (2009 (16)), and the SAAS Development of Science and Technology Fund (No. 2009 (08)).

\section{References}

Rehman S, Kapur N, Durgapal H, Panda SK: Subcellular localization of hepatitis E virus (HEV) replicase. Virology 2008;370:77-92.

-2 Naik SR, Aggarwal R, Salunke PN, Mehrotra $\mathrm{NN}$ : A large waterborne viral hepatitis E epidemic in Kanpur, India. Bull World Health Organ 1992;70:597-604.
Krawczynski K: Hepatitis E. Hepatology 1993; 17:932-941.

4 Ashbolt NJ: Microbial contamination of drinking water and disease outcomes in developing regions. Toxicology 2004;198:229238.
Koopmans M, Duizer E: Foodborne viruses: an emerging problem. Int J Food Microbiol 2004;90:23-41.

6 Khuroo MS: Hepatitis E: The enterically transmitted non-A, non-B hepatitis. Indian J Gastroenterol 1991;10:96-100. 
7 Patra S, Kumar A, Trivedi SS, Puri M, Sarin SK: Maternal and fetal outcomes in pregnant women with acute hepatitis $\mathrm{E}$ virus infection. Ann Intern Med 2007;147:28-33.

-8 Tsega E, Hansson BG, Krawczynski K, Nordenfelt E: Acute sporadic viral hepatitis in Ethiopia: causes, risk factors, and effects on pregnancy. Clin Infect Dis 1992;14:961965.

-9 Jia ZS, Xie YM, Yin GW, Di JR, Guo WP, Huang CX, Bai XF: Successful rescuing a pregnant woman with severe hepatitis $\mathrm{E}$ infection and postpartum massive hemorrhage. World J Gastroenterol 2003;9:631-632.

10 Okamoto H: Genetic variability and evolution of hepatitis E virus. Virus Res 2007;127:216228.

11 Chandra V, Kar-Roy A, Kumari S, Mayor S, Jameel S: The hepatitis E virus ORF3 protein modulates epidermal growth factor receptor trafficking, STAT3 translocation, and the acute-phase response. J Virol 2008;82:71007110.

12 Chandra V, Taneja S, Kalia M, Jameel S: Molecular biology and pathogenesis of hepatitis E virus. J Biosci 2008;33:451-464.

-13 Tam AW, Smith MM, Guerra ME, Huang CC, Bradley DW, Fry KE, Reyes GR: Hepatitis $E$ virus: molecular cloning and sequencing of the full-length viral genome. Virology 1991; 185:120-131.

14 Reyes GR, Purdy MA, Kim JP, Luk KC, Young LM, Fry KE, Bradley DW: Isolation of a cDNA from the virus responsible for enterically transmitted non-A, non-B hepatitis. Science 1990;247:1335-1339.

$\checkmark 15$ Huang CC, Nguyen D, Fernandez J, Yun KY, Fry KE, Bradley DW, Tam AW, Reyes GR: Molecular cloning and sequencing of the Mexico isolate of hepatitis E virus. Virology 1992;191:550-558.

16 Graff J, Zhou YH, Torian U, Nguyen H, St Claire M, Yu C, Purcell RH, Emerson SU: Mutations within potential glycosylation sites in the capsid protein of hepatitis E virus prevent the formation of infectious virus particles. J Virol 2008;82:1185-1194.

$\checkmark 17$ Kalia M, Chandra V, Rahman SA, Sehgal D, Jameel S: Heparan sulfate proteoglycans are required for cellular binding of the hepatitis $\mathrm{E}$ virus ORF2 capsid protein and for viral infection. J Virol 2009;83:12714-12724.

18 Riddell MA, Li F, Anderson DA: Identification of immunodominant and conformational epitopes in the capsid protein of hepatitis $\mathrm{E}$ virus by using monoclonal antibodies. J Virol 2000;74:8011-8017.

19 Chandra V, Kalia M, Hajela K, Jameel S: The ORF3 protein of hepatitis E virus delays degradation of activated growth factor receptors by interacting with CIN 85 and blocking formation of the Cbl-CIN85 complex. J Virol 2010;84:3857-3867.

20 Yamada K, Takahashi M, Hoshino Y, Takahashi $\mathrm{H}$, Ichiyama $\mathrm{K}$, Tanaka T, Okamoto $\mathrm{H}$ : Construction of an infectious cDNA clone of hepatitis E virus strain JE03-1760F that can propagate efficiently in cultured cells. J Gen Virol 2009;90:457-462.

21 Panda SK, Thakral D, Rehman S: Hepatitis E virus. Rev Med Virol 2007;17:151-180.

22 Haqshenas G, Shivaprasad HL, Woolcock PR, Read DH, Meng XJ: Genetic identification and characterization of a novel virus related to human hepatitis $E$ virus from chickens with hepatitis-splenomegaly syndrome in the United States. J Gen Virol 2001;82:2449-2462.

23 Garkavenko O, Obriadina A, Meng J, Anderson DA, Benard HJ, Schroeder BA, Khudyakov YE, Fields HA, Croxson MC: Detection and characterisation of swine hepatitis $\mathrm{E}$ virus in New Zealand. J Med Virol 2001;65:525529.

24 Banks M, Heath GS, Grierson SS, King DP, Gresham A, Girones R, Widen F, Harrison TJ: Evidence for the presence of hepatitis $\mathrm{E}$ virus in pigs in the United Kingdom. Vet Rec 2004; 154:223-227.

25 Ning H, Niu Z, Yu R, Zhang P, Dong S, Li Z: Identification of genotype 3 hepatitis $\mathrm{E}$ virus in fecal samples from a pig farm located in a Shanghai suburb. Vet Microbiol 2007;121: 125-130.

26 Sakano C, Morita Y, Shiono M, Yokota Y, Mokudai T, Sato-Motoi Y, Noda A, Nobusawa $T$, Sakaniwa $H$, Nagai A, Kabeya $H$, Maruyama S, Yamamoto S, Sato H, Kimura $\mathrm{H}$ : Prevalence of hepatitis $\mathrm{E}$ virus infection in wild boars (Sus scrofa leucomystax) and pigs in Gunma prefecture, Japan. J Vet Med Sci 2009;71:21-25.

27 Takahashi M, Tamura K, Hoshino Y, Nagashima S, Yazaki Y, Mizuo H, Iwamoto S, Okayama M, Nakamura Y, Kajii E, Okamoto $\mathrm{H}$ : A nationwide survey of hepatitis $\mathrm{E}$ virus infection in the general population of Japan. J Med Virol 2010;82:271-281.

28 Si F, Yang Q, Zhu Y, Dong S, Yu R, Shen S, Li $Z$ : Adaptation of genotype 3 hepatitis $\mathrm{E}$ virus in Eastern China and inverse correlation with genotype 4 hepatitis $\mathrm{E}$ virus. Intervirology 2012;55:356-364.

29 Zhao C, Ma Z, Harrison TJ, Feng R, Zhang C, Qiao Z, Fan J, Ma H, Li M, Song A, Wang Y: A novel genotype of hepatitis $\mathrm{E}$ virus prevalent among farmed rabbits in China. J Med Virol 2009;81:1371-1379.

-30 Johne R, Plenge-Bonig A, Hess M, Ulrich RG, Reetz J, Schielke A: Detection of a novel hepatitis E-like virus in faeces of wild rats using a nested broad-spectrum RT-PCR. J Gen Virol 2010;91:750-758.

31 Johne R, Heckel G, Plenge-Bonig A, Kindler E, Maresch C, Reetz J, Schielke A, Ulrich RG: Novel hepatitis E virus genotype in Norway rats, Germany. Emerg Infect Dis 2010;16:1452-1455.

32 Johne R, Dremsek P, Kindler E, Schielke A, Plenge-Bonig A, Gregersen $\mathrm{H}$, Wessels $\mathrm{U}$, Schmidt K, Rietschel W, Groschup MH, Guenther S, Heckel G, Ulrich RG: Rat hepatitis E virus: geographical clustering within Germany and serological detection in wild Norway rats (Rattus norvegicus). Infect Genet Evol 2012;12: 947-956.
33 Li TC, Yoshimatsu K, Yasuda SP, Arikawa J, Koma T, Kataoka M, Ami Y, Suzaki Y, Mai le TQ, Hoa NT, Yamashiro T, Hasebe F, Takeda N, Wakita T: Characterization of self-assembled virus-like particles of rat hepatitis $\mathrm{E}$ virus generated by recombinant baculoviruses. J Gen Virol 2011;92:2830-2837.

-34 Purcell RH, Engle RE, Rood MP, KabraneLazizi Y, Nguyen HT, Govindarajan S, St Claire M, Emerson SU: Hepatitis E virus in rats, Los Angeles, California, USA. Emerg Infect Dis 2011;17:2216-2222.

35 Drexler JF, Seelen A, Corman VM, Fumie Tateno A, Cottontail V, Melim Zerbinati R, Gloza-Rausch F, Klose SM, Adu-Sarkodie Y, Oppong SK, Kalko EK, Osterman A, Rasche A, Adam A, Muller MA, Ulrich RG, Leroy EM, Lukashev AN, Drosten C: Bats worldwide carry hepatitis $\mathrm{E}$ virus-related viruses that form a putative novel genus within the family Hepeviridae. J Virol 2012;86:9134-9147.

36 Batts W, Yun S, Hedrick R, Winton J: A novel member of the family Hepeviridae from cutthroat trout (Oncorhynchus clarkii). Virus Res 2011;158:116-123.

37 Lu L, Li C, Hagedorn CH: Phylogenetic analysis of global hepatitis E virus sequences: genetic diversity, subtypes and zoonosis. Rev Med Virol 2006; 16:5-36.

38 Meng XJ: Hepatitis E virus: animal reservoirs and zoonotic risk. Vet Microbiol 2010;140: 256-265.

39 Meng XJ: Recent advances in hepatitis E virus. J Viral Hepat 2010;17:153-161.

40 Si F, Zhu Y, Dong S, Yu S, Yu R, Shen S, Yang $\mathrm{Q}, \mathrm{Li} \mathrm{Z}$ : Full genomic sequence analysis of swine genotype 3 hepatitis $\mathrm{E}$ virus isolated from Shanghai. Virus Res 2009;144:290-293.

-41 Zhang W, He Y, Wang H, Shen Q, Cui L, Wang X, Shao S, Hua X: Hepatitis E virus genotype diversity in eastern China. Emerg Infect Dis 2010;16:1630-1632.

42 Karetny IV, Dzhumalieva D, Usmanov R, Titova I, Litvak II, Balaian M: The possible involvement of rodents in the spread of viral hepatitis E. Zh Mikrobiol Epidemiol Immunobiol 1993;4:52-56.

43 Kabrane-Lazizi Y, Fine JB, Elm J, Glass GE Higa H, Diwan A, Gibbs CJ Jr, Meng XJ, Emerson SU, Purcell RH: Evidence for widespread infection of wild rats with hepatitis $\mathrm{E}$ virus in the United States. Am J Trop Med Hyg 1999;61:331-335.

44 Favorov MO, Kosoy MY, Tsarev SA, Childs JE, Margolis HS: Prevalence of antibody to hepatitis E virus among rodents in the United States. J Infect Dis 2000;181:449-455.

45 Hirano M, Ding X, Li TC, Takeda N, Kawabata H, Koizumi N, Kadosaka T, Goto I, Masuzawa T, Nakamura M, Taira K, Kuroki T, Tanikawa $\mathrm{T}$, Watanabe H, Abe K: Evidence for widespread infection of hepatitis E virus among wild rats in Japan. Hepatol Res 2003;27:1-5.

46 Wang X, Chang Y, Wang L, Geng J, Bu Q, Fu $\mathrm{H}$, Zhu Y: Experimental infection of SD rats with swine hepatitis E virus. Chin J Zoonoses 2011;01:33-36. 
47 Li Z, Yu S, Dong S, Zhu Y, Si F, Shen S, Jiang Z, Yu R, Zou S: Reduced prevalence of genotype $3 \mathrm{HEV}$ in Shanghai pig farms and hypothetical homeostasis of porcine HEV reservoir. Vet Microbiol 2009;137:184-189.

48 Huang YW, Haqshenas G, Kasorndorkbua C, Halbur PG, Emerson SU, Meng XJ: Capped RNA transcripts of full-length cDNA clones of swine hepatitis $\mathrm{E}$ virus are replication competent when transfected into Huh7 cells and infectious when intrahepatically inoculated into pigs. J Virol 2005;79:1552-1558.

49 Huang FF, Pierson FW, Toth TE, Meng XJ Construction and characterization of infectious cDNA clones of a chicken strain of hepatitis E virus (HEV), avian HEV. J Gen Virol 2005;86:2585-2593.
50 Kwon HM, LeRoith T, Pudupakam RS, Pierson FW, Huang YW, Dryman BA, Meng XJ: Construction of an infectious cDNA clone of avian hepatitis E virus (avian HEV) recovered from a clinically healthy chicken in the United States and characterization of its pathogenicity in specific-pathogen-free chickens. Vet Microbiol 2011;147:310-319.

51 Li W, Sun Q, She R, Wang D, Duan X, Yin J, Ding Y: Experimental infection of Mongolian gerbils by a genotype 4 strain of swine hepatitis E virus. J Med Virol 2009;81:1591-1596.

2 Maneerat Y, Clayson ET, Myint KS, Young GD, Innis BL: Experimental infection of the laboratory rat with the hepatitis $\mathrm{E}$ virus. J Med Virol 1996;48:121-128.

53 Halbur PG, Kasorndorkbua C, Gilbert C, Guenette D, Potters MB, Purcell RH, Emerson SU, Toth TE, Meng XJ: Comparative pathogenesis of infection of pigs with hepatitis $\mathrm{E}$ viruses recovered from a pig and a human. J Clin Microbiol 2001;39:918-923.
54 Aggarwal R, Kamili S, Spelbring J, Krawczynski K: Experimental studies on subclinical hepatitis E virus infection in cynomolgus macaques. J Infect Dis 2001;184:1380-1385.

55 Feagins AR, Opriessnig T, Huang YW, Halbur PG, Meng XJ: Cross-species infection of specific-pathogen-free pigs by a genotype 4 strain of human hepatitis E virus. J Med Virol 2008;80:1379-1386.

56 Meng XJ, Halbur P, Haynes J, Tsareva T, Bruna J, Royer R, Purcell R, Emerson S: Experimental infection of pigs with the newly identified swine hepatitis E virus (swine HEV), but not with human strains of HEV. Arch Virol 1998;143:1405-1415. 